Ekuitas: Jurnal Pendidikan Ekonomi

Volume 9, Number 1, Tahun 2021, pp. 116-126

P-ISSN : 2354-6107 E-ISSN : 2549-2292

DOI : $10.23887 /$ ekuitas.v9i1.28267

Open Access: https://ejournal.undiksha.ac.id/index.php/EKU

\title{
Produktivitas Kerja Karyawan Berdasarkan Upah dan Lingkungan Kerja
}

\author{
Luh Ayu Yustika Dewi ${ }^{1 *}$, I Nyoman Sujana ${ }^{2}$ \\ 1,2Universitas Pendidikan Ganesha, Singaraja-Indonesia
}

\begin{tabular}{l} 
A R T I C L E I N F O \\
\hline Article history: \\
Received August, 252020 \\
Received in revised form \\
June, 82021 \\
Accepted June, 82021 \\
Available online June, 28 \\
2021 \\
\hline Kata Kunci: \\
Upah, lingkungan kerja, \\
produktivitas kerja \\
karyawan. \\
Keywords: \\
Employee Work \\
Productivity, Wage, Work \\
Environment.
\end{tabular}

\begin{abstract}
A B S T R A K
Riset ini bertujuan buat menguji pengaruh (1) upah terhadap produktivitas kerja karyawan di Industri UD. PB Sari Muda, (2) area kerja terhadap produktivitas kerja karyawan di Industri UD. PB Sari Muda, (3) upah serta area kerja terhadap produktivitas kerja karyawan di Industri UD. PB Sari Muda. Tipe riset yang digunakan dalam riset ini merupakan riset kausal. Subjek riset ini merupakan segala karyawan yang bekerja pada Industri UD. PB sari Muda. Objek riset ini berfokus pada variable upah, area kerja serta produktivitas kerja karyawan. Informasi dikumpulkan dengan metode wawancara, kuesioner, observasi serta dokumentasi yang dianalisis dengan memakai analisis regresi linier berganda. Perolehan riset menampilkan kalau: (1) Secara segmental variabel upah (X1) mempengaruhi positif serta substansial terhadap produktivitas kerja karyawan $(\mathrm{Y})$ di Industri UD. PB Sari Muda sebesar 16, $3 \%$, (2) Secara segmental variabel area kerja (X2) mempengaruhi positif
\end{abstract} serta substansial terhadap produktivitas kerja karyawan (Y) di Industri UD. PB Sari Muda sebesar 83, 6\% serta (3) Pengaruh upah (X1) serta area kerja (X2) secara serempak mempengaruhi positif serta substansial terhadap produktivitas kerja karyawan (Y) di Industri UD. PB Sari Muda sebesar 97, 5\% serta sisanya 2,5\% dipengaruhi oleh variabel lain.

\section{A B S T R A C T}

This study aims to examine the effect of (1) wage on the work productivity of employees at UD. PB Sari Muda, (2) the work environment on the work productivity of employees at UD. PB Sari Muda, (3) wage and work environment toward work productivity of employees at UD. PB Sari Muda. This type of research which was used in this research was causal research. The subjects of this research were all employees who work at UD. PB Sari Muda. The object of this research focused on wage, work environment and employee work productivity. The data were collected using interview techniques, questionnaires, observation and documentation which were analyzed by multiple linear regression analysis. The research result show that: (1) Partially, wage variable (X1) had a positive and significant effect on employee work productivity (Y) at UD. PB Sari Muda at 16.3\%, (2) Partially, work environment variable (X2) had a positive and significant effect on employee work productivity (Y) at UD. PB Sari Muda of $83.6 \%$ and (3) The effect of wages (X1) and work environment (X2) serempakeously had a positive and significant effect on employee work productivity (Y) at UD. PB Sari Muda is $97.5 \%$ and the remaining $2.5 \%$ is influenced by other variables.

Copyright @ Ekuitas: Jurnal Pendidikan Ekonomi. All rights reserved. 


\section{Pendahuluan}

Pertumbuhan dunia usaha di Indonesia spesialnya dalam bidang penciptaan beras dikala ini hadapi kenaikan yang begitu pesat. Perihal ini dibuktikan dengan bagi Badan Pusat Statistik Indonesia( 2019), kalau perkembangan penciptaan di Indonesia hadapi kenaikan sebesar 4, 35\%. Meningkatnya pertumbahan penciptaan di Indonesia sebab meningkatnya perolehan produktivitas di sesuatu industri. Dalam upaya tingkatkan produktivitas di sesuatu industri tidak terlepas dari SDM yang dipunyai. SDM memegang peranan berarti dalam sesuatu industri sebab senantiasa berfungsi aktif serta dominan dalam tiap aktivitas industri. Bali ialah pulau yang mempunyai kekayaan alam yang begitu indah, salah satu pariwisata yang populer di Bali sebab panorama alam sawah serta subak. Dengan terdapatnya sawah, perihal ini pasti saja masih terdapat warga yang bekerja bagaikan petani sawah, bagi Badan Pusat Statistik Provinsi Bali( 2019), kalau penduduk bali yang bekerja bagaikan petani sawah tercatat sebanyak $21,64 \%$. Dengan terdapatnya warga yang bekerja bagaikan petani pasti saja banyak pelakon usaha yang bergerak dalam zona penciptaan beras.

Di wilayah Buleleng spesialnya Kecamatan Sawan ada 3 industri yang sejenis ialah bergerak dalam zona penciptaan beras. Terdapatnya industri yang sejenis serta terletak dalam satu kawasan menyebabkan terbentuknya persaingan antar industri. Oleh sebab itu, keberperolehanan sesuatu industri buat mempertahankan keberadaannya di dunia bisnis, wajib bisa menyesuaikan diri dengan pergantian yang dialami sehingga tujuan diresmikan berjalan cocok dengan yang direncanakan. Proses pencapaian tujuan itu pastinya tidak cuma didetetapkan oleh besarnya dana pembedahan, canggihnya teknologi maupun prasarana yang dipunyai, namun pula bergantung aspek SDM. Kenaikan daya produksi karyawan memerlukan management yang cakap dalam mengoptimalkan perolehan yang diraih dengan keahlian fondasi manusia lewat penjatahan tugas serta tanggung jawab yang hendak membikin kerja sama dalam organiisasi. Keberperolehanan sesuatu organiisasi tergantung pada daya produksi yang dimilki baik secara perorangan maupun regu di dalam organiisasi tersebut. Secara umum produktivitas yakni komparatif antara perolehan yang diraih( output) dengan keseluruhan sumber tenaga manusia yang digunakan( input). Untuk (Hariandja, 2002), jika faktor- aspek yang mempengaruhi produktivitas kerja yakni kemampuan, atmosfer dan keadaan zona kerja, motivasi, upah, tingkatan pendidikan, kesepakatan kerja, dan penerapan teknologi. Terdapat pula untuk (Indrayani, L., Djatmika, E.T., Wahjoedi, \& Witjaksono, 2018), jika produktivitas bisa diraih melalui aktivitas penciptaan. Tidak cuma itu, untuk (Pandji, 2000), jika faktor- aspek yang memengaruhi daya produksi kerja yakni motivasi kerja karyawan, pendidikan, disiplin kerja, kemampuan, sikap etika kerja, kemampuan kerja sama, gizi dan kesehatan, tingkatan upah/ pendapatan, zona kerja dan hawa kerja, kecanggihan teknologi, faktor- aspek penciptaan yang memadai.

Dalam upaya tingkatkan produktivitas kerja, upah serta area kerja yang baik bisa mendukung keberperolehanan sesuatu industri dalam menggapai tujuannya. Bagi (Sukarno, 2015), kalau terus menjadi baiknya upah serta area kerja hingga produktivitas kerja karyawan hendak terus menjadi bertambah. Bersumber pada penjelasan tersebut bisa dilihat kalau salah satu aspek berarti yang pengaruhi produktivitas tenaga kerja ialah upah yang diterima oleh para pekerja. Bagi (Setiadi, 2009), kalau besar kecilnya upah yang diberikan kepada pekerjanya hendak pengaruhi besar rendahnya tingkatan produktivitas kerja karyawan. Perihal ini sejalan dengan riset bagi (Sumarlin, Syarief, Ritonga, 2010) disebutkan upah kedayagunaan dari Caffety( 1990), kalau produktivitas kerja tergatung pada tingkatan upah yang mereka terima. Perolehan riset tersebut sejalan dengan riset yang (Ardika, 2014), (Rustariyuni, 2018), kalau upah mempengaruhi positive terhadap produktivitas kerja karyawan. Aspek lain yang bisa pengaruhi produktivitas kerja merupakan area kerja. Lngkungan kerja yang baik asa bisa memperlekas daya produksi kerja karyawan yang besar. Bagi (Afandi, 2016), kalau khasiat area kerja merupakan mengperolehankan gairah kerja, sehingga produktivitas bertambah. Bagi riset yang dicoba oleh Senata (2012), kalau area kerja mempengaruhi positive serta substansial terhadap produktivitas kerja karyawan. Perolehan riset tersebut sejalan dengan riset yang dicoba oleh (Gufran, 2012), (Apriani, 2012), (Lestari, 2019), (Sinaga, 2016), (Anitasari, 2007), (Kristina, 2015), kalau area kerja mempengaruhi positive serta substansial terhadap produktivitas kerja karyawan.

Industri yang diteliti merupakan UD. PB Sari Muda yang didukung oleh 35 karyawan. Industri UD. PB Sari Muda ialah industri yang bergerak dalam zona penciptaan. Bersumber pada observasi dini nampak kalau terjalin penyusutan produktivitas kerja, perihal ini ditunjukkan dari belum tercapainya sasaran industri, pada bulan Juni industri sanggup memproduksi beras sebanyak 105 ton dengan tingkatan presentase ketercapaian 70\%, berikutnya pada bulan Juli industri cuma sanggup meproduksi beras sebanyak 75 ton dengan tingkatan presentase ketercapaian 50\%, berikutnya pada bulan Agustus industri cuma memproduksi beras sebanyak 45 ton beras dengan tingkatan presentase ketercapaian 
cuma 30\%, serta pada bulan September perolehan penciptaan beras cuma 40 ton dengan tingkatan presentase ketercapaian sebesar $27 \%$.

Rendahnya produktivitas kerja karyawan diakibatkan sebab pemberian upah yang tidak cocok dan pemberian upah yang tidak pas waktu yang diberikan kepada segala karyawan sehingga banyak karyawan yang melaksanakan pinjaman kepada industri buat penuhi kebutuhan hidup karyawan. Tidak hanya itu, rendahnya produktivitas kerja sebab dipengaruhi oleh area kerja yang kurang kontributif serta aman dibuktikan dengan banyaknya karyawan yang melaksanakan absensi tiap bulannya. Tidak hanya itu, kerap terjalin konflik sebab kesalah pahaman serta tutur bahasa yang kurang sopan antar karyawan yang menimbulkan perselisihan antar karyawan.

Tidak hanya itu, bersumber pada observasi langsung yang sudah dicoba penulis memandang kalau produktivitas pada Industri UD. PB Sari Muda wajib ditingkatkan lagi, perihal ini bisa dilihat dari aktivitas tiap hari dalam melaksanakan tugas serta pekerjaannya, masih terdapat karyawan yang tiba terlambat dari jam masuk yang sudah didetetapkan, rehat yang sangat lama, kembali sangat dini. Bersumber pada penjelasan di atas, nampak kalau produktivitas kerja karyawan dari bulan Juni- September 2019 terjalin penyusutan, sementara itu produktivitas kerja ini sangat dibutuhkan untuk Industri UD. PB Sari Muda bagaikan industri yang bergerak dalam bidang penciptaan. Terlebih dalam persaingan pasar menuntut teliti dalam menyajikan produk cocok dengan permintaan pasar dengan mutu yang memuaskan. Buat menggapai perihal tersebut, industri wajib membagikan atensi yang lebih kepada karyawan dalam tingkatkan perolehan produktivitas sehingga industri bisa menggapai laba yang optimal. Tujuan riset ini merupakan buat mengenali( 1) pengaruh upah terhadap produktivitas kerja karyawan di Industri UD. PB Sari Muda,(2) pengaruh area kerja terhadap produktivitas kerja karyawan di Industri UD. PB Sari Muda,( 3) pengaruh upah serta area kerja terhadap produktivitas kerja karyawan di Industri UD. PB Sari Muda.

Upah ialah aspek yang sangat berarti untuk industri, sebab jumlah upah ataupun balasn jasa yang diberikan kepada karyawannya hendak mempunyai pengaruh yang besar terhadap jalannya industri. Bagi Susila (2016), kalau upah mempunyai pengaruh positive serta substansial terhadap produktivitas kerja. Terus menjadi tingi upah hingga bisa tingkatkan konsentrasi serta memunculkan rasa semangat bekerja sehingga bisa tingkatkan produktivitas kerja. Perihal ini sejalan dengan riset yang dicoba oleh (Lestari, 2019), kalau upah mempengaruhi positive substansial terhadap produktivitas kerja. Bagi (Hasibuan, 2009), kalau upah merupakan balasn jasa yang di bayarkan kepada pekerja setiap hari dengan mengacu atas kesepakatan yang disepakati paymentnya. Tak hanya itu, bagi Sukirno( 2003: 353), kalau upah dalam teori ekonomi dimaksud bagaikan pembayaran yang diraih bermacam bentu jasa yang disediakan serta diberikan oleh tenaga kerja kepada para pengusaha. Bagi (Shaleh, 2018), kalau upah merupakan kompensasi langsung dalam wujud finansial yang didapatkan oleh karyawan bersumber pada pada jam kerja, satuan benda yang diraihankan ataupun jumlah karyawan yang diberikan bila berbentuk industri jasa. Bagi (Hariandja, 2002), kalau upah merupakan balasn jasa dalam wujud duit yang diterima pekerja bagaikan konsekuensi dari perannya bagaikan seseorang pekerja yang membagikan sumbangan dalam menggapai tujuan organisasi. Bagi Hadi( 2014: 38), kalau upah merupakan jumlah totalitas yang diresmikan bagaikan pengganti jasa yang dikeluarkan oleh tenaga kerja maupun karyawan melalui masa dan syarat- ketentuan tertentu. Untuk (Veithzal Rivai, 2009), jika upah ialah balasn jasa yang adil dan layak diberikan kepada para pekerja atas jasa- jasanya dalam mencapai suatu tujuan organisasi. Bersumber pada komentar para pakar di atas, hingga bisa dirangkum kalau upah ialah kompensasi finansial yang diterima pekerja atas balasn jasa yang diterima karyawan pada dikala bekerja dalam menggapai tujuan organisasi. Dalam riset ini merujuk pada teori bagi (Hariandja, 2002).

Ukuran upah bagi (Hariandja, 2002), kalau ukuran upah merupakan( 1) keadilan internal( internal equity). Jumlah yang diraih dipersepsi sesuai dengan input yang diberikan dibandingkan dengan pekerjaan yang sama dalam industri.( 2) keadilan eksternal( external equity). Jumlah yang diterima dibandingkan dengan yang diterima dalam pekerjaan yang sejenis diluar organisasi. Sebaliknya bagi (Veithzal Rivai, 2009), kalau ukuran upah merupakan( 1) Adil, didalam membagikan upah wajib senantiasa mencermati prinsip keadilan, keadilan ini bukan berarti kalau seluruh suatu wajib di untuk rata, namun keadilan yang wajib dihubungkan antara pengorbanan( input) dengan pemasukan( output),( 2) Layak, didalam membagikan upah wajib pula mencermati pula faktor kelayakan. Kelayakan sistem pengupahan bisa dilihat dengan menyamakan sistem pengupahan industri lain. Penanda upah yang digunakan dalam riset ini bagi (Hariandja, 2002), kalau penanda upah merupakan( 1) upah yang diterima cocok dengan tugas, tanggung jawab, serta tingkatan usaha yang dicoba,(2) upah yang diterima cocok dengan upah yang terdapat di industri lain buat pekerjaan yang sama,(3) Upah yang diterima cocok dengan UMR.

Area kerja ialah salah satu aspek berarti dalam tingkatkan produktivitas kerja karyawan. Atmosfer area kerja yang nyaman serta kontributif memiliki pengaruh langsung terhadap kenyamanan karyawan dalam melaksanakan kegiatan bekerja. Perihal ini sejalan dengan riset yang dicoba oleh (Abdul \& Wandi, 
2019), kalau area kerja mempengaruhi positive serta substansial terhadap produktifitas kerja karyawan. Terus menjadi baik serta aman area kerja, hingga hendak mendesak karyawan supaya bahagia bekerja serta tingkatkan rasa tanggung jawab buat melaksanakan pekerjaan dengan lebih baik sehingga karyawan sanggup tingkatkan produktivitas kerja karyawan. Bagi (Mardiana, 2015), kalau area kerja merupakan area yangmana pegawai melaksanakan pekerjaannya tiap hari. Area kerja yang kontributif hendak membagikan rasa nyaman serta membolehkan para pegawai buat bisa bekerja maksimal. Tidak hanya itu, bagi (Sedarmayanti, 2009), kalau area kerja merupakan totalitas perlengkapan perkakas serta bahan yang dialami, area dekat di mana seseorang bekerja, tata cara kerja, dan pengaturan kerja( baik bagaikan perseorangan ataupun bagaikan kelompok). Bagi Supardi( 2003: 37), kalau area kerja ialah kondisi dekat tempat kerja baik secara raga serta non raga yang bisa membagikan kesan yang mengasyikkan, mengamankan, menetramkan, betah kerja serta lain sebagainya. Sebaliknya bagi (Hariandja, 2002), kalau area kerja merupakan kondisi di mana tempat karyawan bekerja yang menyangkut seluruh sarana kerja baik raga serta psikologis sehingga karyawan bisa melaksanakan tugas dengan baik serta tenang. Bersumber pada komentar para pakar di atas, hingga bisa dirangkum kalau area kerja ialah segala kondisi di mana seorang bisa bekerja dengan baik serta tenang sehingga sanggup melaksanakan tugas yang dibebankan. Dalam riset ini merajuk pada teori (Hariandja, 2002).

Ukuran area kerja Bagi (Hariandja, 2002) adalah ( 1) area kerja raga, ialah menyangkut sarana kerja,( 2) area kerja psikologis, ialah menyangkut ikatan kerja. Sebaliknya bagi (Sedarmayanti, 2009), kalau area kerja mempunyai 2 ukuran, bagaikan berikut( 1) area kerja raga, ialah seluruh yang ada disekitar tempat bekerja serta yang bisa pengaruhi pekerja baik secara langsung ataupun tidak langsung. Bagi (Robbins, 2002), kalau area kerja raga ialah aspek pemicu stress kerja pegawai yang mempengaruhi terhadap prestasi kerja pegawai,( 2) area kerja non raga, merupakan seluruh kondisi yang terjalin berkaitan dengan ikatan kerja, baik dengan atasan ataupun dengan sesama rekan kerja maupun ikatan dengan bawahan. Penanda area kerja yang digunakan dalam riset ini bagi (Hariandja, 2002) merupakan( 1) atmosfer kerja, keadaan yang terdapat di dekat karyawan yang lagi melaksanakan pekerjaan yang bisa pengaruhi penerapan pekerjaan itu sendiri,( 2) ikatan dengan rekan kerja.( a) ikatan atasan dengan bawahan terjalin dikala atasan membagikan tugas dalam melaksanakan pekerjaan kepada bawahannya. Bagi (Hariandja, 2002), kalau penyampaian data dari pimpinan ke bawahan dapat meliputi banyak perihal semacam tugas- tugas yang wajib dicoba bawahan, kebijakan organisasi, tujuan- tujuan yang mau di capai serta terdapatnya pergantian- pergantian kebijakan. Ikatan ataupun interaksi antara bawahan wajib dilindungi dengan harmonis serta silih melindungi etika dan menghargai satu sama lain supaya terciptanya area kerja yang aman. Area kerja yang aman hendak membuat kedua belah pihak antara atasan dengan bawahan bisa silih tingkatkan produktivitas kerja,( b) ikatan antar karyawan. Bagi (Hariandja, 2002), ikatan antar karyawan merupakan ikatan kesamping antara karyawan dengan tingkatan yang sama dalam organisasi namun mereka memiliki tugas yang berbeda. Menjalakan ikatan yang baik serta harmonis sesama karyawan ialah fasilitas buat bisa tingkatkan produktivitas,( 2) tersedianya sarana kerja. Perihal ini berarti mencakup sarana kerja ialah perlengkapan yang di pakai buat menunjang kelancaran kerja lengakap sehingga karyawan sanggup bekerja secara maksimal.

Produktivitas kerja secara universal ialah komparatif antara perolehan yang diraih( output) dengan kesulurah sumberr energi yang digunakan( input). Produktivitas kerja merupakan dimensi dari mutu serta kuantitas dari pekerjaan yang sudah dikerjakan, dengan memikirkan bayaran karyawan yang digunakan buat mengerjakan pekerjaan. Bagi (Hasibuan, 2008), kalau produktivitas komparatif antara perolehan( output) dengan masukan( input). Bila produktivitas naik hendak tingkatkan kedayagunaan( waktu- bahan- tenaga) serta sistem kerja, metode penciptaan serta terdapatnya kenaikan keahlian dari tenaga kerjanya. Bagi Ardana dkk.( 2013: 270), kalau komparatif daya guna menciptakan terbitan( output) dengan kedayagunaan pemakaian sumber- sumber masukan( input). Bagi Sutrisno( 2017: 207), kalau produktivitas ialah output per unit, ataupun output dipecah input, ataupun rasio antara output dengan input. Bagi Triton( 2007: 80), kalau produktivitas kerja ialah bagaikan komparatif perolehanperolehan yang diraih dengan kesuluruhan sumber energi yang dipergunakan ataupun komparatif jumlah penciptaan( output) dengan sumber energi yang digunakan( input). Tidak hanya itu, bagi (Hariandja, 2002), kalau produktivitas ialah perilaku mental yang melatarbelakangi karyawan buat capaian kerja kearah yang bagus dari hari kemarin. Penafsiran itu memiliki arti kalau dalam industri, karyawan wajib seterusnya melaksanakan revisi proses penciptaan, sistem kerja, area kerja serta lain- lain supaya perolehan yang diraih cocok dengan prospek industri. Dari sebagian komentar para pakar di atas, hingga bisa dirangkum kalau produktivitas kerja ialah perfoma kerja yang baik dalam melaksanakan revisi proses penciptaan, sistem kerja, area kerja dalam memajukan sesuatu industri. Dalam teori ini periset merajuk pada teori (Hariandja, 2002).

Bagi (Hariandja, 2002), kalau produktivitas kerja mempunyai 2 ukuran bagaikan berikut( 1) daya guna, ukuran daya guna berkaitan dengan pencapaian unjuk kerja yang optimal,( 2) kedayagunaan, 
berkaitan dengan upaya menyamakan masukan dengan realisasi penggunaannya ataupun gimana pekerjaan tersebut dilaksanakan. Sebaliknya bagi (Sedarmayanti, 2009), kalau ukuran dalam produktivitas kerja merupakan( 1) kedayagunaan, ialah sesuatu dimensi dalam menyamakan pemakaian masukan( input) yang direncanakan dengan pemakaian masukan yang sesungguhnya terlaksanakan. Apabila masukan yang sesungguhnya digunakan terus menjadi besar penghematannya, hingga tingkatan kedayagunaan terus menjadi besar, tetapi terus menjadi kecil masukan yang bisa dihemat, sehingga terus menjadi rendah tingkatan kedayagunaan. Penafsiran kedayagunaan disini lebih berorientasi kepada masukan sebaliknya permasalahan terbitan( output) kurang jadi atensi utama,(2) daya guna. ialah sesuatu dimensi yang membagikan cerminan sebarapa jauh sasaran bisa tercapai. Penafsiran daya guna ini lebih berorientasi kepada terbitan sebaliknya permasalahan pemakaian masukan kurang jadi atensi utama. Apabila kedayagunaan berhubungan dengan efektifitas hingga meski terjalin kenaikan daya guna belum pasti kedayagunaan bertambah,(3) mutu, ialah sesuatu dimensi yang melaporkan seberapa jauh sudah dipadati bermacam persyaratan, spesifikasi serta prospek. Konsep ini bisa cuma berorientasi kepada masukan, terbitan ataupun keduanya. Di samping itu mutu pula berkaitan dengan proses penciptaan. yang hendak mempengaruhi pada mutu perolehan yang diraih totalitas.

Untuk (Hariandja, 2002), jika indikator produktivitas kerja bagaikan berikut( 1)kuantitas kerja, sesuatu perolehan yang diraih oleh karyawan sawaktu tertentu dengan komparatif tolak ukur yang terdapat ataupun diresmikan oleh industri,( 2) mutu kerja, sesuatu tolak ukur perolehan yang berkaitan dengan kualitas dari sesuatu produk yang diraihankan oleh karyawan dalam Menimpa ini ialah sesuatu keahlian karyawan dalam menuntaskan pekerjaan secara teknis dengan komparatif tolak ukur yang diresmikan oleh industri,(3) akurasi waktu, tingkatan sesuatu kegiatan dituntaskan pada dini waktu yang di tentukan, dilihat dari dari sudut penyelarasan dengan perolehan output dan mengoptimalkan waktu yang ada buat kegiatan lain. Akurasi waktu diukur dari anggapan karyawan terhadap sesuatu kegiatan yang disediakan di dini waktu hingga jadi output.

\section{Metode}

Tipe riset yang digunakan dalam riset ini merupakan riset kausal. Bagi (Sugiyono, 2016), kalau riset kausal ialah riset yang bertabiat karena akibat, sehingga dalam riset ini ada variable leluasa( independent variable) yang digunakan dalam riset ini meliputi variable upah(X1) serta variable area kerja( X2) serta variable terjalin( dependent variable) ialah produktivitas kerja karyawan( Y). Tipe informasi dalam riset ini merupakan informasi kuantitatiif. Informasi kuantitatif dalam riset ini berbentuk angka- angka dari perolehan kuesoiner yang diisi oleh karyawan ialah berbentuk informasi upah, area kerja serta produktivitas kerja. Sumber informasi dalam riset ini merupakan informasi primer serta informasi sekunder. Informasi primer ialah informasi yang di bisa langsung dari tempat riset di UD. PB Sari Muda berbentuk informasi upah, informasi area kerja, informasi produktivitas kerja. Informasi sekunder ialah informasi yang diraih secara langsung dari responden namun dari pihak ketiga ialah berbentuk catatan nama serta jumlah karyawan pada industri UD. PB Sari Muda.

Bagi (Sugiyono, 2016), kalau metode pengumpulan informasi yang digunakan dalam riset ini bagaikan berikut:( 1 ) interview( wawancara), merupakan metode pengumpulan informasi lewat tanya jawab langsung kepada pihak- pihak yang terpaut buat menciptakan kasus yang wajib di cermat, dalam perihal ini metode pengambilan informasi dicoba dengan metode mengadakan tanya jawab langsung kepada pemiliki industri serta kepada karyawan yang bekerja di industri UD. PB Sari Muda apabila periset mau mengenali hal- hal responden yang lebih mendalam serta jumlah responden sedikit/ kecil,( 2) kuesioner( angket), ialah metode pengumpulan informasi yang dicoba dengan metode berikan seperangkat persoalan ataupun statment tertulis kepada responden ialah segala karyawan industri UD. PB Sari Muda. Kuesioner ini berbentuk persoalan yang berkaitan dengan upah, area kerja serta produktivitas kerja. Dimana kuesioner diukur memakai skala likert,( 3) observasi, ialah aktivitas pengumpulan informasi yang dicoba dengan metode melaksanakan pengamatan langsung ke obyek yang diteliti buat mendapatkan informasi yang akurat terhadap obyek riset, dalam perihal ini merupakan industri UD. PB Sari Muda,( 4) dokumentasi, dalam riset ini dokumentasi digunakan buat mendapatkan informasi industri semacam informasi jumlah karyawan, informasi upah yang diterima oleh karyawan, informasi absensi karyawan serta informasi perolehan produktivitas industri.

Periset melaksanakan pengujian kuesioner terlebih dulu saat sebelum melaksanakan riset yang sesungguhnya. Uji coba terhadap kuesioner tersebut dicoba buat mengenali valid serta reliabel sesuatu kuesioner yang hendak digunakan dalam riset,( 1) Uji Validitas, ialah kesesuaian antara perlengkapan ukur dengan tujuannya. Dalam riset ini perlengkapan pengumpulan informasi yang digunakan wajib penuhi persyaratan. Kuesioner upah, area kerja, serta produktivitas kerja karyawan saat sebelum 
digunakan mengumpulkan informasi, terlebih dulu diuji cobakan buat mengenali validitas serta reliabilitas dalam menangkapkan apa yang hendak diukur. Uji validitas dilakoni dengan rumus pertalian Product Moment serta perlengkapan bantu program SPSS tipe 22. 0 for windows. Item kuesioner dalam uji validitas dikatakan valid bila nilai rhitung dari rtabel serta nilai signifikasi 0,05 . Kebalikannya item dikatakan tidak valid bila nilai $r_{\text {hitung }}<r_{\text {tabel }}$ serta pada nilai substansial 0, 05 .

\section{Rumus Pertalian Product Moment.}

$r_{x y}=$

$$
\frac{\mathrm{n} \sum x y-\left(\sum x\right)\left(\sum y\right)}{\sqrt{\left(\mathrm{n} .\left(\sum x^{2}\right)-\left(\sum \mathrm{x}\right)\right)^{2}\left(\mathrm{n} . .\left(\sum y^{2}\right)-\left(\sum \mathrm{y}\right)\right)^{2}}} \quad \text { (Sumber. Umar (2009: 166) }
$$

(2) Uji Reliabilitas, sesuatu kuesioner dikatakan reliabel( profesional) bila jawaban responden terhadap statment yang terdapat dalam kuesioner tersebut merupakan tidak berubah- ubah dari waktu ke waktu. Keputusan buat mengenali kalau instrumen merupakan reliabel bagi (Ghozali, 2002), kalau statment dinyatakan reliabel bila nilai $\mathrm{r}$ Alpha Cronbach 0, 6. Analisis informasi yang digunakan_dalam riset ini ialah analisis regresi linier berganda, sebab berdarkan paradigma yang diprakiraan tidak terdapat keterkaitan ataupun pertalian antar variable leluasa. Buat menolong proses pengolahan informasi secara kilat serta pas, hingga pengolahan informasinya dicoba dengan memakai program SPSS tipe 22. 0 for windows. Saat sebelum informasi diolah ke analisis regresi linier berganda, hingga terlebih dulu diuji dengan pengujian anggapan klasik, sebab ketentuan buat analisis regresi linier berganda merupakan leluasa dari asumsi- asumsi klasik semacam:( 1) Uji Normality, bertujuan buat menguji apakah dalam model regresi, variable leluasa serta variable terjalin keduanya memiliki diseminasi wajar ataupun tidak. Model regresi yang baik merupakan yang berdiseminasi wajar ataupun mendekati wajar. Uji t serta uji F mengasumsikan kalau nilai residual menjajaki diseminasi nornal. Pada prinsipnya normality bisa didekati dengan memandang penyebaran informasi( titik) pada sumbu diagonal serta diagram ataupun dengan memandang histogram dari risidualnya. Landasan penentuan ketetapan dalam uji normality ialah bagaikan berikut: ( a) apabila residual informasi memencar disekitar garis diagonal serta menjajaki arah garis diagonal ataupun diagram histogramnya menampilkan rupa diseminasi wajar, hingga model regresi penuhi anggapan normality,( b) apabila residual informasi memencar jauh dari garis diagonal serta/ tidak menjajaki arah garis diagonal ataupun diagram histogram tidak meyakinkan rupa distribus wajar, hingga model regresi tidak penuhi anggapan normality. Secara statistik bisa menggunakan uji Kolmogrov- Smirnov( K- S). Uji statistik simpel bisa dicoba dengan memandang nilai Kolmogrov- Smirnov dari residual, ( 2) Uji Multikolinearitas, bertujuan buat menguji apakah dalam model regresi ditemui terdapatnya pertalian antar variable leluasa( independent variable). Model regresi yang baik sepatutnya tidak terjalin pertalian antara variable leluasa. Apabila variable leluasa silih berpertalian, hingga variable- variable ini tidak orthogonal. Variable orthogonal yakni variable leluasa yang nilai pertalian antar sesama variable leluasa sama dengan nol( Ghozali: 2006: 95). Uji Multikolinieritas. bisa dilihat dari tolerance value serta nilai Variance Inflation Factor( VIF). Dasar pengambilan keputusan dalam uji multikolinieritas yakni bagaikan berikut:( a) apabila tolerance value 10\%. Serta nilai VIF $<10$, hingga bisa dirangkum bila tidak terdapat indikasi multikolinieritas antar variable leluasa dengan model regresi,( b) apabila tolerance value $<10 \%$. Serta nilai VIF 10 , hingga bisa dirangkum bila terdapat indikasi multikolinieritas antar variable leluasa dengan model regresi.( 3) Uji Heterroskedastisitas, ialah salah satu dari uji asumsi klasik yang harus dicoba pada regresi linier berganda. Uji heterroskedastisitas bertujuan buat menguji apakah dalam model regresi terjalin ketidaksamaan variance dari residual satu pengamatan ke pengamatan lain tetap, sampai diucap homoskedastisitas dan apabila berbeda diucap heterroskedastisitas( Ghozali, 2016: 125). Model regresi yang baik ialah tidak terjalin heterroskedastisitas. Tata cara buat mengenali ada maupun tidaknya heterroskedastisitas dengan memandang diagram plot antara nilai prakiraan variable terjalin yakni ZPREAD dengan nilai residualnya SRESID. Deteksi ini tidaknya rupa tertentu pada diagram scatterplot. Dasar pengambilan keputusan ialah bagaikan berikut:( a) apabila ada rupa tertentu, semacam titik- titik yang membikin rupa khusus yang tertib, sampai mengidentifikasi telah terjalin heterroskedastisitas,( b) apabila tidak ada rupa yang jelas, serta titik- titik yang memencar di atas dan dibawah angka 0 pada sumbu $Y$, sampai tidak terjalin heterroskedastisitas. 
Analisis yang digunakan dalam riset ini merupakan analisis regresi linier berganda sebab variable yang digunakan lebih dari 2 variable dan bersumber pada paradigma yang diprakiraan tidak terdapat keterkaitan ataupun pertalian antar variable leluasa. Regresi linier berganda dicoba buat mengenali sepanjang mana variable leluasa pengaruhi variable terjalin. Analisis Regresi Analisis Regresi linier berganda bertujuan buat menganilisis pengaruh variable leluasa( independent variable) yang digunakan dalam riset ini meliputi variable upah( X1) serta variable area kerja( X2) serta variable terjalin( dependent variable) ialah produktivitas kerja karyawan( $Y$ ). Hingga rumus yang digunakan dalam riset ini bagaikan berikut.

Rumus:

$$
Y=a+\beta_{1} X_{1}+\beta_{2} X_{2}+e
$$

Sumber. Sugiyono (2009: 258)

dimana :

$\mathrm{Y}=$ Produktivitas Kerja

a = Nilai Konstanta

$\mathrm{X}_{1}=$ Upah

$\mathrm{X}_{2}$ = Lingkungan Kerja

$\mathrm{b}_{1}=$ koefisien regresi dari $\mathrm{X}_{1}$

$\mathrm{b}_{2}=$ koefisien regresiu dari $\mathrm{X}_{2}$

Untuk mengetahui substansial dari dari perolehan penelitian maka perlu dilakukan beberapa uji hipotesis, yaitu uji secara serempak (Uji F) dan uji secara segmental (uji t).

\section{Hasil dan pembahasan}

Perolehan studi ini menunjukkan jika:(1). Bersumber pada uji t terhadap variable upah(X1), dapat dinyatakan perolehan $t$ hitung sebesar 2,371 dengan probabilitas $t$ sebesar 0,024 . Karena $t_{\text {hitung }}<t_{\text {tabel }}(2$, $371<1,694)$ maupun tingkatan substansialsi t lebiih rendah dari $5 \%(0,024<0,05)$, sampai secara segmental variable upah(X1) dapat dinyatakan mempunyai pengaruh substansial terhadap produktivitas karyawan( Y). Nilai t positive menampakkan jika variable X1 mempunyai jalinan yang searah dengan Y. Jadi dapat dirangkum jika H1 diterima yakni upah pengaruhi secara segmental terhadap produktivitas kerja karyawan di Industri UD. PB Sari Muda. Besarnya pengaruh segmental Upah( X1) terhadap Produktivitas Kerja( Y) disimak dari nilai tolak ukurdized coefficients beta sebesar 0, 163( 16, 3\%). Terdapat pula perolehan uji t terlihat di tabel 1.

Tabel 1. Perolehan Perhitungan Uji t Pengaruh Upah $\left(\mathrm{X}_{1}\right)$ Secara Segmental Terhadap Produktivitas Kerja Karyawan (Y) di Perusahaan UD.PB Sari Muda.

\section{Coefficients $^{\mathrm{a}}$}

\begin{tabular}{|c|c|c|c|c|c|c|}
\hline \multirow{2}{*}{\multicolumn{2}{|c|}{ Model }} & \multicolumn{2}{|c|}{ Untolak ukurdized Coefficients } & \multirow{2}{*}{$\begin{array}{c}\text { Tolak ukurdized } \\
\text { Coefficients } \\
\text { Beta } \\
\end{array}$} & \multirow[t]{2}{*}{$\mathrm{T}$} & \multirow[t]{2}{*}{ Sig. } \\
\hline & & $\mathrm{B}$ & Std. Error & & & \\
\hline \multirow{3}{*}{1} & (Constant) & 4,755 &, 555 & & 8,571 & 000 \\
\hline & Upah &, 087 & 037 &, 163 & 2,371 &, 024 \\
\hline & $\begin{array}{l}\text { Lingkungan } \\
\text { Kerja }\end{array}$ & ,707 & 058 & ,836 & 12,179 & ,000 \\
\hline
\end{tabular}

a. Dependent Variable: Produktivitas Kerja Karywan

(2). Bersumber pada uji $\mathrm{t}$ ( uji segmental) terhadap variable area kerja( $\mathrm{X} 2$ ) didapat perolehan thitung sebesar 12, 179 dengan probabilitas t sebesar 0, 000. Sebab thitung $>t_{\text {tabel }}(12,179>1,694)$ ataupun tingkatan substansialsi t lebiih rendah dari $5 \%(0,000<0,05)$, hingga secara segmental variable area kerja( X2) bisa dinyatakan memiliki pengaruh substansial terhadap produktivitas kerja karyawan( Y). Nilai $\mathrm{t}$ positive menampilkan kalau variable area kerja( X2) memiliki ikatan yang searah dengan produktivitas kerja karyawan( Y). Jadi bisa dirangkum kalau pengujian hipotesis kedua bisa dilihat kalau variable Area Kerja(X2) memiliki nilai substansialsi sebesar 0, 000 yang maksudnya p- value $0,000<0$, 05, hingga bisa dinyatakan kalau variable Area Kerja( X2) memiliki pengaruh substansial terhadap Produktivitas Kerja Karyawan( Y). Jadi bisa dirangkum kalau H2 diterima ialah Area Kerja( X2) 
mempengaruhi secara segmental serta substansial terhadap Produktivitas Kerja Karyawan( Y) di Industri UD. PB Sari Muda. Ada pula perolehan perhitungan uji t terlihat pada tabel 2.

Tabel 2. Perolehan Perhitungan Uji t Pengaruh Lingkungan Kerja $\left(X_{2}\right)$ Secara Segmental Terhadap Produktivitas Kerja Karyawan (Y) di Perusahaan UD.PB Sari Muda.

Coefficients $^{\mathbf{a}}$

\begin{tabular}{|c|c|c|c|c|c|c|}
\hline \multirow{2}{*}{\multicolumn{2}{|c|}{ Model }} & \multicolumn{2}{|c|}{ Untolak ukurdized Coefficients } & \multirow{2}{*}{$\begin{array}{c}\begin{array}{c}\text { Tolak ukurdized } \\
\text { Coefficients }\end{array} \\
\text { Beta } \\
\end{array}$} & \multirow[t]{2}{*}{$\mathrm{T}$} & \multirow[t]{2}{*}{ Sig. } \\
\hline & & $\mathrm{B}$ & Std. Error & & & \\
\hline \multirow{3}{*}{1} & (Constant) & 4,755 &, 555 & & 8,571 &, 000 \\
\hline & Upah &, 087 & 037 & ,163 & 2,371 & ,024 \\
\hline & $\begin{array}{l}\text { Lingkungan } \\
\text { Kerja }\end{array}$ & ,707 & 058 & ,836 & 12,179 & 000 \\
\hline
\end{tabular}

a. Dependent Variable: Produktivitas Kerja Karywan

(3). Bersumber pada uji F terhadap variable upah serta area kerja menampilkan kalau nilai dari Fhitung sebesar 657, 456 lebih besar dari nilai Ftabel 3, 29 ataupun p_value $=0,000<0,05$. Jadi bisa dirangkum kalau Ha diterima serta H0 ditolak dengan demikian Upah( X1) serta Area Kerja( X2) secara serempak mempengaruhi positive serta substansial terhadap Produktivitas Kerja Karyawan( Y). Perihal ini menampilkan kalau variable X secara bersama- sama pengaruhi variable Y. Perihal ini berarti kalau, H3 diterima. Perolehan Uji F Terlihat pada tabel 3.

Tabel 3. Perolehan Perhitungan Uji F Pengaruh Upah (X1) dan Lingkungan Kerja (X2) Secara Serempak Terhadap Produktivitas Kerja Karyawan (Y) di Perusahaan UD.PB Sari Muda.

\begin{tabular}{llrrrrr}
\multicolumn{7}{c}{ ANOVA $^{\mathbf{a}}$} \\
\hline Model & \multicolumn{1}{c}{ Sum of Squares } & df & Mean Square & F & \multicolumn{1}{c}{ Sig. } \\
\hline \multirow{2}{*}{1} & Regression & 1196,761 & 2 & 598,381 & 657,456 &, $000^{\mathrm{b}}$ \\
\cline { 2 - 7 } & Residual & 29,125 & 32 &, 910 & & \\
\cline { 2 - 8 } & Total & 1225,886 & 34 & & & \\
\hline
\end{tabular}

a. Dependent Variable: Produktivitas Kerja Karywan

b. Predictors: (Constant), Lingkungan Kerja, Upah

Besarnya pengaruh upah dan lingkungan kerja terhadap produktivitas kerja karyawan pada perusahaan UD. PB Sari Muda dapat diketahui dari koefisien determinasi, yang dipertunjukkan dengan besar Adjusted R Square. Perolehan analisis koefisien determinasi dapat disajikan pada table 4 .

Tabel 4. Koefisien Determinasi

Model Summary

\begin{tabular}{ccccc}
\hline Model & $\mathrm{R}$ & R Square & Adjusted R Square & $\begin{array}{c}\text { Std. Error of the } \\
\text { Estimate }\end{array}$ \\
\cline { 2 - 4 } 1 &, $988^{\mathrm{a}}$ &, 976 &, 975 &, 954 \\
\hline
\end{tabular}

a. Predictors: (Constant), Lingkungan Kerja, Upah

Besarnya pengaruh Upah serta Area Kerja terhadap Produktivitas Kerja Karyawan secara serempak sebesar 0, 975 ataupun sebesar 97, 5\% serta sisanya 2, 5\% dipengaruhi oleh variable lain. Bersumber pada perhitungan analisis regresi linier berganda, bisa dinyatakan perolehan persamaan regresi yaitu:

$$
\mathrm{Y}=8,571+2,371 \mathrm{X}_{1}+12,179 \mathrm{X}_{2}+\epsilon
$$

Bersumber pada model regresi di atas, hingga bisa diinterprestasikan bagaikan berikut.( 1$)$ Konstanta 8, 571 membuktikan, kalau apbila variable upah serta area kera bernilai konstan, hingga ratarata nilai variable produktivitas kerja karyawan merupakan sebesar 8, 571,(2) Koefisien regresi upah sebesar 2, 371, berarti kalau apabila ada akumulasi variable upah sebesar 1 satuan, hingga nilai produktivitas kerja hendak meningkat sebesar 3. 371 satuan dengan anggapan kalau variable yang lain bernilai konstan,(3) Koefisien regresi area kerja sebesar 12, 179 berarti kalau apabila ada akumulasi area 
kerja sebesar 1 satuan, hingga nilai produktivitas karyawan hendak meningkat sebesar 13, 179 satuan dengan anggapan kalau variable bernilai konstan..

\section{Pembahasan}

Bersumber pada riset yang berdialog permasalahan upah pastinya mempunyai pengaruh besar dalam upaya kenaikan produktivitas kerja karyawan. Bersumber pada perolehan riset, bisa diambil sesuatu kesimpulan kalau upah mempengaruhi substansial terhadap produktivitas kerja karyawan terhadap industri UD. PB Sari Muda. Perihal ini berarti kalau terus menjadi besar upah yang diberikan, hingga produktivitas kerja karyawan hendak terus menjadi bertambah. Maksudnya, bila industri membagikan upah yang adil serta cocok dengan jumlah penciptaan yang diraihankan oleh karyawan, hingga hendak bisa membagikan rasa semangat bekerja sehingga produktivitas kerja karyawan hendak bertambah. Bersumber pada yang terjalin di lapangan pemberian upah yang rendah serta tidak pas waktu menimbulakan rasa malas dalam bekerja, perihal ini bisa dilihat dari keseharian karyawan yang bekerja diperusahaan tersebut. Terdapatnya pemberian upah yang adil serta layak sangat diharapkan oleh karyawan, perihal ini sebab bagi karyawan yang bekerja di industri UD. PB Sari Muda dia bekerja demi memperoleh sesuatu pemasukan bagaikan pendorong bayaran hidup. Dengan membagikan upah yang adil serta layak hendak membuat karyawan merasa sudah dicermati atas kerja keras yang mereka jalani. Dalam keadaan semacam ini karyawan hendak merasa bergairah serta disiplin dalam bekerja sehingga perolehannya hendak tingkatkan produktivitas kerja karyawan. Perolehan riset ini sejalan teori yang dikemukakan oleh (Hariandja, 2002) yang melaporkan kalau upah ialah balasn jasa dalam wujud duit yang diterima karyawan bagaikan seseorang bekerja. Apabila seseorang karyawan memperoleh upah adil serta cocok dengan peraturan kerja hingga hendak bisa menimbulkan produktivitas pekerja bertambah. Tidak hanya itu, teori ini didukung oleh. (Pandji, 2000), kalau upah yang lumayan hendak membagikan semangat kerja karyawan sehingga produktivitas kerja hendak tercapai. Perolehan riset ini di dukung oleh perolehan riset terdahulu yang dicoba oleh Kurniawan( 2010) yang menciptakan kalau upah mempengaruhi positive serta substansial terhadap produktivitas kerja karyawan. Di perkuat lagi oleh perolehan riset yang dicoba oleh (Lestari, 2019), kalau upah mempengaruhi positive serta substansial terhadap produktivitas kerja karyawan.

Bersumber pada perolehan riset, bisa diambil sesuatu simpulan kalau area kerja mempengaruhi positive serta substansial terhadap produktivitas kerja karyawan pada industri UD. PB Sari Muda. Bersumber pada kenyataanya yang terjalin dilapangan sistem kerja di industri UD. PB Sari Muda berkelompok serta apabila terjalin konflik hingga pekerjaan hendak jadi terhambat sehingga produktivitas kerja karyawan hendak menyusut. Area kerja yang aman serta nyaman hendak membetulkan moral karyawan serta intensitas kerja karyawan. Komunikasi serta kerja sama yang baik antara segala komponen industri, atmosfer kerja yang aman, dan perlengkapan yang lengkap dalam melaksanakan pekerjaan serta kebersihan di tempat bekerja sangat menolong kedayagunaan kerja karyawan sehingga mengperolehankan rasa betah serta aman dalam melaksanakan sesuatu pekerjaan sehingga bisa tingkatkan produktivitas kerja karyawan. Perolehan riset ini didukung teori yang dikemukakan oleh (Hariandja, 2002) dimana seluruh yang menyangkut sarana kerja raga serta non raga karyawan baik serta tenang hingga bisa tingkatkan produktivitas kerja. perihal ini di dukung oleh teori yang diungkapkan oleh (Pandji, 2000), kalau area kerja yang aman hendak mempu tingkatkan produktivitas kerja karyawan. Perolehan riset ini didukung oleh perolehan riset terdahulu yang dicoba oleh (Gufran, 2012), (Apriani, 2012), (Lestari, 2019)(Lestari, 2013), kalau area kerja mempengaruhi positive serta substansial terhadap produktivitas kerja karyawan. Perolehan riset ini pula diperkuat oleh riset yang dicoba oleh (Sinaga, 2016), kalau area kerja mempengaruhi positive serta substansial terhadap produktivitas kerja karyawan.

Bersumber pada perolehan riset bisa diambil sesuatu simpulan kalau secara serempak upah serta area kerja mempengaruhi positive serta substansial terhadap produktivitas kerja karyawan. Perihal ini berarti upah serta area kerja ialah faktor- faktor yang pengaruhi produktivitas kerja karyawan. Ditinjau dari upah, terdapatnya pemberian upah yang dicoba oleh pihak industri buat penuhi kebutuhan hidup karyawan serta keluarganya, apabila kehidupan hidup mereka terpenuhi hingga karyawan yang bekerja di industri tersebut hendak merasa dihargai serta karyawan hendak membagikan tenaga serta pikirannya kepada industri. Perihal ini berarti terus menjadi besar pengorbanan yang dicoba oleh karyawan, terus 
menjadi besar pemasukan yang diberikan oleh pihak industri mengingat upah yang diberikan oleh pihak industri bergantung dari perolehan yang diraih oleh karyawan sepanjang bekerja. Perihal ini hendak memacu karyawan buat bekerja lebih aktif serta mendapatkan pemasukan yang besar. Pemberian balasn jasa dalam wujud duit oleh pihak industri dimaksudkan bagaikan perlengkapan buat mendesak kenaikan produktivitas kerja. Dengan pemberian upah, diharapkan karyawan bisa bekerja lebih produktif serta memiliki tanggung jawab penuh terhadap tugasnya, sehingga sasaran volume penciptaan industri bisa terpenuhi. Tidak hanya itu, dengan terdapatnya upah yang layak serta adil hendak menjalakan ikatan yang baik antara karyawan kepada pihak industri, sehingga segala tenaga kerja hendak berupaya tingkatkan produktivitas kerja. Ditinjau dari area kerja, pada dasarnya seorang yang bekerja hendak menginginkan atmosfer kerja yang nyaman dan area kerja yang aman. Dengan terdapatnya area kerja yang semacam itu diharapkan karyawan hendak bekerja lebih baik, lebih produktif serta semangat dalam bekerja. Tidak hanya itu, area kerja yang mengasyikkan hendak pengaruhi karyawan bekerja lebih semangat dalam menuntaskan pekerjaan sehingga produktivitas kerja bertambah dan sasaran industri bisa terpenuhi. Perolehan riset ini didukung dengan teori (Hariandja, 2002), kalau produktivitas kerja karyawan dipengaruhi oleh aspek upah serta area kerja. Bila upah yang diberikan oleh pihak industri adil serta cocok hingga produktivitas karyawan hendak bertambah. Apabila area kerja karyawan aman serta nyaman hingga karyawan hendak betah dalam bekerja serta produktivitas kerja karyawan hendak bertambah. Teori ini pula diperkuat dengan (Pandji, 2000), kalau dalam upaya tingkatkan produktivitas kerja karyawan dipengaruhi oleh aspek upah serta area kerja. Perolehan riset ini didukung oleh perolehan riset terdahulu yang dicoba oleh (Sukarno, 2015), kalau upah serta area kerja mempengaruhi positive serta substansial terhadap produktivitas kerja karyawan, maksudnya terus menjadi baiknya upah serta area kerjamaka produktivitas kerja karyawan hendak terus menjadi bertambah. Tidak hanya itu, diperkuat lagi dengan riset yang dicoba oleh (Yoni, 2019), kalau secara serempak upah serta area kerja mempengaruhi positive terhadap produktivitas kerja karyawan.

\section{Simpulan dan saran Simpulan}

Bersumber pada pada perolehan analisis informasi yang sudah dicoba buat mengenali pengaruh upah serta area kerja terhadap produktivitas kerja karyawan pada Industri UD. PB Sari Muda, hingga bisa dirangkum bagaikan berikut:( 1) Secara segmental variable upah( X1) mempengaruhi positive serta substansial terhadap produktivitas kerja karyawan( Y) di Industri UD. PB Sari Muda sebesar 16, 3\%,( 2) Secara segmental variable area kerja( X2) mempengaruhi positive serta substansial terhadap produktivitas kerja karyawan( Y) di Industri UD. PB Sari Muda sebesar 83, 6\%,( 3) Pengaruh upah( X1) serta area kerja( X2) secara serempak mempengaruhi positive serta substansial terhadap produktivitas kerja karyawan( Y) di Industri UD. PB Sari Muda sebesar 97, 5\% serta sisanya 2, 5\% dipengaruhi oleh variable lain.

\section{Saran}

Bersumber pada simpulan di atas, hingga penulis mau mengantarkan saran- anjuran sekiranya bermanfaat untuk manajemen. Dari perolehan riset ini, hingga dianjurkan pada pihak industri buat mencermati pemberian upah yang adil serta layak semacam halnya melaksanakan pemberian upah yang pas waktu serta membagikan upah yang setara dengan industri lain sehingga motivasi kerja karyawan hendak bertambah serta membagikan rasa semangat dalam melaksanakan pekerjaan sehingga produktivitas kerja hendak bertambah serta industri hendak bisa penuhi permintaan pasar dilapangan. Tidak hanya itu, membagikan sarana area kerja yang aman semacam halnya menjalakan komunikasi yang baik antar karyawan, ataupun antar atasan serta bawahan sangat dibutuhkan dalam membetulkan moral karyawan serta intensitas kerja karyawan. tidak hanya itu, industri wajib memenuhi kebutuhan karyawan semacam tersedianya P3K sangat berarti demi melindungi keselamatan kerja karyawan tidak hanya itu pihak industri ataupun karyawa wajib melindungi kebersihan dengan optimal sehingga karyawan merasa betah dalam melaksanakan kegiatan kerja dan merasa bergairah dalam menuntaskan pekerjaanya sehingga industri sanggup menggapai sasaran serta bisa tingkatkan produktivitas kerja yang maksimal. Pada riset selanjutnya dianjurkan supaya menaikkan variable bebasnya semacam keahlian, motivasi, tingkatan pembelajaran, kesepakatan kerja dan pelaksanaan teknologi, serta lain- lain. Akumulasi variable leluasa dimaksudkan sebab produktivitas kerja karyawan tidak cuma dipengaruhi oleh upah serta area kerja semata melainkan variable lain yang mempengaruhinya. 


\section{Daftar Rujukan}

Abdul, L., \& Wandi, W. (2019). Analisis Faktor-Faktor Yang Mempengaruhi Produktivitas Kerja Karyawan Pada Biro Penggadaan Jasa PT. Semen PadangAnalisis Faktor-Faktor Yang Mempengaruhi Produktivitas Kerja Karyawan Pada Biro Penggadaan Jasa PT. Semen Padang. Jurnal Sains Dan Teknologi, Vol. 19, N, 25-60.

Afandi, P. (2016). Conpect \& Indicator Human Resources Management for Management Reseath. Yogyakarta. Anitasari. (2007). Pengaruh Lingkungan Kerja dan Kepuasan Kerja Terhadap Produktivitas Kerja Karyawan. Apriani, W. R. (2012). Pengaruh Kompensasi dan Lingkungan Kerja Terhadap Produktivitas Kerja Karyawan PT. BPR Restu Artha Makmur Kantor Pusat Majapahit Semarang. Jurnal Universitas Dipenogoro Semarang, Vol 1 Nomo, 252-260.

Ardika, S. (2014). Pengaruh Upah dan Pengalaman Kerja Terhadap Produktivitas Karyawan Kerajinan Ukiran Kabupaten Subang. Jurnal Ekonomi Trikonomika, Vol. 13 No, 91-100.

Ghozali. (2002). Metode Penelitian. Jakarta: Guna Dharma.

Gufran. (2012). Pengaruh Lingkungan Kerja dan Disiplin Kerja. Terhadap Produktivitas Kerja Karyawan PT. POS Indonesia (Persero).

Hariandja, M. T. . (2002). Manajemen Sumber Daya Manusia. Jakarta: Grasindo.

Hasibuan, M. S. . (2008). Manajemen Dasar, Pengertian, dan Masalah. Jakarta: PT. Bumi Aksara.

Hasibuan, M. S. . (2009). Manajemen Sumber Daya Manusia. Jakarta: PT. Bumi Aksara.

Indrayani, L., Djatmika, E.T., Wahjoedi, \& Witjaksono, M. (2018). Collective Action Performed By Webbing Bamboo Craftwomen At Kayubihi Village, Bali, Indonesia. International Journal Of Civil Engineering and Technology (IJCIET), 9(6), 872-886.

Kristina. (2015). Pengaruh Lingkungan Kerja Terhadap Produktivitas Melalui Kepuasan Kerja (Survey Pada Karyawan Usaha Mikro Kecil dan Menengah (UMKM).

Lestari. (2013). Pengaruh Pelatihan Kerja, Lingkungan Kerja Fisik serta Motivasi Terhadap Produktivitas Kerja Karyawan di PT. Taspen (Persero) Kantor Cabang Denpasar.

Lestari, A. W. (2019). Pengaruh Motivasi, Pelatihan, Lingkungan Kerja dan Upah Terhadap Produktivitas Kerja Karyawan PT. Truba Jaya. Jurnal Intelektualitas, Vol. 8 Nom, 47-56.

Mardiana. (2015). Manajemen Produksi. Jakarta: IPWI.

Pandji, A. (2000). Manajemen Bisnis. Jakarta: Rineka Cipta.

Robbins, P. S. (2002). Prinsip-Prinsip Perilaku Organisasi. Jakarta.

Rustariyuni, N. (2018). Pengaruh Upah dan Teknologi Terhadap Produktivitas dan Penyerapan Tenaga Kerja Pada Industri Mebel di Kota Denpasar. Jurnal Kependudukan Dan Pengembangan Sumber Daya Manusia, 14(1), 34-48.

Sedarmayanti. (2009). Sumber Daya Manusia dan Produktivitas Kerja. Bandung: Mandar Maju.

Setiadi. (2009). Pengaruh Upah dan Jaminan Sosial Terhadap Produktivitas Kerja Karyawan di PT. Makmur Semarang. Jurnal Universitas Dipenogoro Semarang.

Shaleh, B. (2018). Manajemen Sumber Daya Manusia. Aksara Timur.

Sinaga, I. (2016). Pengaruh Lingkungan Kerja Terhadap Produktivitas Kerja Karyawan (Bagian Produksi Minyak Kelapa Sawit PT. Mitra Unggul Pusaka Segati Pelalawan Riau). JOM FISIP, 3(2), 1-13.

Sugiyono. (2016). Metode Penelitian Kuantitafi, Kualitatif Dan R\&D. Bandung: Alfabeta.

Sukarno, B. H. (2015). Pengaruh Upah dan Lingkungan Kerja Terhadap Produktivits Kerja Karyawan di PT. Mondrian Garment Manufacture Klaten. Jurnal Universitas Dipenogoro Semarang.

Sumarlin, Syarief, Ritonga, S. (2010). Analisis Hubungan Tingkat Upah Tinggi Terhadap Produktivitas di Indonesia. Jurnal Mepa Ekonomi USU.

Veithzal Rivai, E. J. S. (2009). Manajemen Sumber Daya Manusia Untuk Perusahaan. Jakarta: Rajawali Pers.

Yoni, P. (2019). Analisis Faktor-Faktor yang Mempengaruhi Produktivitas Tenaga Kerja Industri Kecil (Studi UD. Maju Makmur). 